\title{
Starvation effects on physiological parameters and biochemical composition of the hepatopancreas of the southern king crab Lithodes santolla (Molina, 1782)
}

\author{
Efectos del ayuno sobre parámetros fisiológicos y composición bioquímica del \\ hepatopancreas de la centolla Lithodes santolla (Molina, 1782) \\ Laura Comoglio ${ }^{1}$, Jesica Goldsmit ${ }^{2}$ and Oscar Amin ${ }^{1}$
${ }^{1}$ Centro Austral de Investigaciones Científicas (CADIC - CONICET) (V9410BDF) Ushuaia -Tierra del Fuego, Argentina
${ }^{2}$ Universidad Nacional de Córdoba, Córdoba, Argentina
lcomoglio@cadic.gov.ar

\begin{abstract}
Resumen.- Este estudio evalúa los efectos del ayuno en la centolla Lithodes santolla. Machos adultos de la centolla fueron mantenidos en condiciones de ayuno durante 12 días. Cada 3 días (i.e., 0, 3, 6, 9 y 12 días) se evaluó en subgrupos el consumo de oxígeno, la excreción de amonio, la relación atómica $\mathrm{O}: \mathrm{N}$ y la composición bioquímica del hepatopáncreas. El índice hepatosomático (calculado individualmente como el porcentaje del peso húmedo del hepatopáncreas en relación al peso húmedo total del individuo) fue menor a 12 días de ayuno, coincidiendo con el menor contenido de proteínas en el hepatopáncreas. No se detectaron diferencias significativas en la composición bioquímica porcentual (contenido de agua, materia orgánica y cenizas). El contenido lipídico no fue significativamente diferente durante el experimento aunque el mayor valor fue registrado a los 3 días de ayuno. Entre los 3 y 9 días de ayuno, la excreción de amonio y el contenido de proteínas en el hepatopáncreas fue mayor y la actividad enzimática de tripsina, menor. Esto podría indicar que el catabolismo de proteínas fue el más importante durante ese período. Este hecho también se confirma por los bajos valores de $\mathrm{O}: \mathrm{N}$ detectados en el período mencionado. A los 9 días de ayuno se incrementó el consumo de oxígeno, acompañado con un alto valor de excreción de amonio, originados probablemente por una demanda extra de energía producida por el ayuno. Se concluye que $L$. santolla para estos rangos de tiempo experimental utiliza proteínas como fuente primaria de energía.
\end{abstract}

Palabras clave: Cangrejos, consumo de oxígeno, excreción de amonio, lípidos

\section{Introduction}

The southern king crab Lithodes santolla (Molina) together with Paralomis granulosa (Jacquinot) are the most important shellfish in Tierra del Fuego, Argentina. L. santolla is distributed from Chiloe (South Pacific) to Tierra del Fuego, and from the Magellan Strait to Uruguay (South Atlantic) (Macpherson 1988).

Nutritional deprivation is a natural part of the life cycle

\begin{abstract}
This study evaluates the effects of starvation on the physiological aspects of the southern king crab, Lithodes santolla. Adult males of this crab species were maintained in starving conditions for 12 days. Every 3 days (i.e., 0, 3, 6, 9 and 12), subgroups were taken to evaluate oxygen consumption, ammonia excretion, $\mathrm{O}: \mathrm{N}$ atomic ratio and biochemical composition of the hepatopancreas. The hepatosomatic index (calculated individually as the percentage of hepatopancreas wet mass in relation to the total body wet weight) was lower at 12 days starving period, coincidentally with the minor amount of hepatopancreatic protein. No significant differences in the relative biochemical composition (percentage of water, organic matter and ash) were detected. The lipid content was not significantly different during the experiment; nevertheless the higher value was detected at 3 days of starvation. Between the 3 and 9 days of fasting period ammonia excretion and hepatopancreatic protein were higher and the trypsin activity, lower. These results could indicate that protein catabolism was the most important in these periods. Besides, the lower values of $\mathrm{O}: \mathrm{N}$ detected for all periods confirm this effect. On the ninth day of starvation oxygen consumption increased together with a high value of ammonia excretion probably due to an extra energy demand produced by starvation. We conclude that $L$. santolla in the experimental time-range study uses protein as the primary source of energy.
\end{abstract}

Key words: Crabs, oxygen uptake, ammonia excretion, lipids

of many aquatic organisms (Sanchez Paz et al. 2006, Vinagre et al. 2007), which principally occurs during molt processes. Molting in crustaceans involves several stages with different feeding behavior and therefore, different kinds of energy from the available food. Artificially induced fasting and starvation may enlighten the metabolic routes used -in hierarchical order- during molt and may describe novel biochemical and physiological adaptation mechanisms (Barclay et al. 1983). Starvation induction of crustacean in 
the intermolt stage is probably a good model to try to understand the molecular and enzymatic changes that occur naturally during their growing process, although the effect of hormones must not be forgotten (Sanchez Paz et al. 2006). Therefore, starvation studies may be useful predictors to determine energetic and metabolic requirements (Guderley et al. 2003).

As it has been pointed out by Wen et al. (2006), several studies of crustaceans' metabolism have shown high variability of energy reserves mobilization as well as the sequence of substrates used for energy during starvation among crustacean species. The numerous possibilities must be the result of the vast diversity of environments that crustaceans inhabit and their long evolutionary histories (Sanchez Paz et al. 2007).

The hepatopancreas is involved in diverse metabolic activities, such as accumulation and cyclic mobilization of reserves, contribution of nutrients to the ovary during vitellogenesis, digestion and absorption (Sang \& Fotedar 2004, Vazquez Boucard et al. 2004, Hasek \& Felder 2005). In this sense, Sureshkumar \& Kurup (1999) have established that the relative weight of the hepatopancreas reflects the provision of energy utilization for growth and metabolism. Particularly, the hepatopancreas is also considered the major storage organ in decapods crustaceans, mainly accumulating lipids and to a lesser degree, glycogen (see Sanchez Paz et al. 2007), as well as according to Rosas et al. (2000) who support that carbohydrates have low storage capacity and low capability of enzymatic processing.

On the other hand, levels of the digestive enzymes in decapod crustaceans do not remain constant during the developmental cycles (Van Wormhoudt 1974). The most common causes of the alterations of enzymatic values are seasons, circadian rhythm and amount and quality of food (Rodriguez et al. 1994, Fernandez et al. 1997), including the starving conditions (Cuzon et al. 1980, Leung et al. 1990, Comoglio et al. 2004). Among the digestive enzymes detected in crustaceans, trypsin is considered the most important in the digestion of proteins (Fernandez et al. 1997).

A strong relationship between food availability, metabolic rate and biochemical composition of the species considered have been pointed out by Mayzaud (1976). The O:N atomic ratio is considered a good indicator of used substrate for oxidative metabolism (Regnault 1981, Dall \& Smith 1986, Chu \& Ovsianico-Koulikowsky 1994, Rosas et al. 1995). Several theoretical minimum values of the $\mathrm{O}: \mathrm{N}$ ratio have been proposed by different authors for strictly proteinic catabolism, depending on the basis of calculation. In this sense, to compute these theoretical ranges of values it is necessary to take into account the nature of the amino-acids actually entering the Krebs cycle and the catabolic pathway of fatty acids (Mayzaud \& Conover 1988). According to Mayzaud \& Conover (1988) theoretical values between 3 and 16 correspond to catabolism of pure proteins, whereas catabolism of equal quantities of proteins and lipids increases $\mathrm{O}: \mathrm{N}$ ratio form 50 to 60 . Greater values of $\mathrm{O}: \mathrm{N}$ correspond to increase catabolism of lipids and carbohydrates.

Considering the importance to overcome starving periods in the life cycle, the aim of this study was to evaluate the effect of short starving periods on oxygen consumption, ammonia excretion, $\mathrm{O}: \mathrm{N}$ ratio and biochemical composition of hepatopancreas in adult males of Lithodes santolla to describe the patterns of use of reserves.

\section{Material and methods}

\section{Experimental conditions and design}

Adults of L. santolla present different patterns of molt. While females have a molting-mating period during spring months (November-December), males molt during autumn months (March-April) (Vinuesa 1984). On the other hand, the fishery is locally regulated by a protective program which allows extracting only adult males being these under an important fishery pressure. For these reasons, only males were used in the present study in order to have an homogeneous group.

Adult males of L. santolla were provided by the local commercial fishery 'Pesquera del Beagle'. The organisms $(\mathrm{N}=25$; average carapace length $=73.7 \pm 8.4 \mathrm{~mm}$; average wet weight $=292.5 \pm 81.9$ ) were transported to the laboratory and fed ad libitum with fresh mussels Mytilus edulis during two days of acclimation. This period allows the organisms to adapt adequately to the laboratory conditions, and minimize variations due to this factor. The experimental organisms were in intermolt period (Vinuesa 1984).

In the laboratory, crabs were measured (carapace length, CL hereafter; $\pm 0.1 \mathrm{~mm}$ ) and weighed (wet weight; $\pm 0.01 \mathrm{~g}$ ) previously drained. Subgroups of 5 crabs each, were maintained in 60-L glass aquaria for 0 (control group), 3, 6, 9 and 12 starvation days. All groups were maintained at a water salinity of $30 \mathrm{psu}$, a temperature of $8 \pm 0.5^{\circ} \mathrm{C}$ and at a $12: 12 \mathrm{~h}$ light/dark photoperiod cycle. Experimental water was completely renewed daily to avoid eventual consumption of faeces and increment of ammonia concentration.

Seawater was filtered through a $10 \mu \mathrm{m}$ polypropylene cartridge filter and UV-sterilized to minimize the activity of microorganisms, and then kept with constant aeration in $250 \mathrm{~L}$ dark tanks until use. 


\section{Physiological measurements}

After each starving period, organisms were placed individually in $5240 \mathrm{~mL}$ respirometer chambers under a flow-through system (flow $=200 \pm 10 \mathrm{~mL} \mathrm{~min}^{-1}$ ). During the adaptation period and physiological measurements all crabs were maintained in a minimum locomotive activity (routine). To obtain comparable data, all measurements were done at the same time of the day. Crabs were acclimatized for $2 \mathrm{~h}$ to reduce stress and, afterwards, a water sample from each chamber was taken to determine the initial concentration of both oxygen and ammonia. Then, chambers were sealed during $15 \mathrm{~min}$, after which new samples were taken to measure final concentrations. One chamber without crab was added as experimental control for each treatment. Duplicate measurements of each sample were performed. The flow and the sealed period of the chambers were previously adjusted to avoid a depletion of oxygen concentration higher than $0.5 \mathrm{mg} \mathrm{L}^{-1}$.

Oxygen concentration was determined by a polarographic oxygen electrode (YSI@ 5100). Ammonia was determined according to Strickland \& Parsons (1972). Consumed oxygen and excreted ammonia were taken as the net difference between the start and end of the sealed period. The $\mathrm{O}: \mathrm{N}$ atomic ratio was estimated according to Taboada et al. (1998) using the individual values of oxygen consumption and ammonia excretion transformed to $\mu \mathrm{g} \mathrm{At} \mathrm{g}^{-1} \mathrm{~h}^{-1}$.

\section{Biochemical analyses}

After each physiological measurement, crabs were weighed, sacrificed and then the hepatopancreas dissected and weighed $( \pm 0.01 \mathrm{~g})$. Subsamples of approximately $1 \mathrm{~g}$ of hepatopancreas were taken to determine the water and ash content, drying until reaching constant weight at $60^{\circ} \mathrm{C}$ and $550^{\circ} \mathrm{C}$, respectively. For lipid and protein analysis other subsamples of hepatopancreas were frozen until analysis. Lipid content was determined gravimetrically by the method of Bligh \& Dyer (1959). Protein measurements were carried out according to Markwell et al. (1978), reading the optical density at $750 \mathrm{~nm}$ in spectrophotometer. All biochemical measurements were done by duplicate. The hepatosomatic index (HI) was calculated individually as the percentage of hepatopancreas wet weight in relation to the total body wet weight.

\section{Trypsin activity}

Subsamples of approximately $0.5 \mathrm{~g}$ of hepatopancreas were homogenized in $0.1 \mathrm{M}$ Tris buffer $\left(\mathrm{pH} 7.8\right.$ at $\left.4^{\circ} \mathrm{C}\right)$ in $1: 3 \mathrm{w} / \mathrm{v}$ ratio. Homogenates were centrifuged (at 1000 $\mathrm{g}$ for $10 \mathrm{~min}, 4^{\circ} \mathrm{C}$ ) and the aqueous supernatant, diluted
$(1: 10 \mathrm{v} / \mathrm{v})$, and then immediately used for enzyme analysis. Trypsin activity was measured by the method of Erlanger et al. (1961) with N-á-benzoyl-DL-Arg-pnitroanilide (BAPNA) as substrate at $25^{\circ} \mathrm{C}$. The absorbance was measured at $405 \mathrm{~nm}$ and one unit of enzyme activity was defined as $1 \mu \mathrm{mol}$ of p-nitroanilide liberated in $1 \mathrm{~min}$ at $25^{\circ} \mathrm{C}$.

The soluble protein content was measured by the same method described previously. Duplicate assays for each sample were made.

\section{Statistical analysis}

To detect significant differences among starving periods, one-way analysis of variance (ANOVA) was employed after confirmation of normality and homogeneity of variance. For the data to be expressed as percentage, an arcsine transformation was performed. When ANOVA revealed statistically significant differences among groups, a posteriori comparisons (Least Significant Differences) were used to identify which groups differed from one another. When data were not normally distributed, Kruskal-Wallis test and multiple comparisons of Dunn's test (Daniel, 1978) were used. For both tests, $P$ was set at 0.05 . All statistical analyses were performed using STATISTICA (Statsoft) and analyses details were obtained from Sokal \& Rohlf (1981).

\section{Results}

\section{Survival, weight and hepatosomatic index (HI\%)}

During the experiment no mortalities were recorded. Besides, no differences were registered in the weight of crabs related with the initial individual weight (Table 1). The HI was lower at 12 days starving period (3.04 $0.24 \%)$ than at 9 days of starvation $(5.14 \pm 0.15 \%)$. Particularly the average HI at 3 days of starvation was the highest but due to the register of a great deviation no significant differences with the other groups were detected (Table 2, Kruskal-Wallis, $P<0.05$ ).

\section{Oxygen consumption, ammonia excretion and $\mathrm{O}: \mathrm{N}$ ratio}

Oxygen consumption did not differ significantly till 6 days of starving conditions (mean value $25 \pm 9 \mu \mathrm{g} \mathrm{h}^{-1} \mathrm{~g}^{-1}$ ). At 9 days of starvation treatment, oxygen consumption increased significantly $\left(56 \pm 14 \mu \mathrm{g} \mathrm{h}^{-1} \mathrm{~g}^{-1}\right)$ and at 12 days of treatment the consumption diminished again $(37 \pm 2 \mu \mathrm{g}$ $\mathrm{h}^{-1} \mathrm{~g}^{-1}$ ) (ANOVA, $P<0.05$ ) (Fig. 1).

There were significant differences for ammonia excreted during the experiment. The highest values were detected in 3 and 9 starving groups (7.38 \pm 3.30 and $7.33 \pm$ 


\section{Table 1}

Differences in wet mass (mean \pm standard deviation) of Lithodes santolla after each starving period related with the initial weigh expressed as percentage

Diferencias en el peso húmedo (promedio \pm desviación estándar) de Lithodes santolla después de cada período de ayuno en relación al peso inicial, expresado como porcentaje

\begin{tabular}{ccc}
\hline Days of starvation & $\begin{array}{c}\text { Wet mass } \\
\text { (average in g) }\end{array}$ & $\begin{array}{c}\text { Difference in mass related to day 0 } \\
(\%)\end{array}$ \\
\hline 0 & $292.5 \pm 81.9$ & ------ \\
3 & $288.9 \pm 91.3$ & $0.1 \pm 0.9$ \\
6 & $271.6 \pm 98.9$ & $0.0 \pm 1.0$ \\
9 & $267.5 \pm 122.1$ & $-0.3 \pm 2.3$ \\
12 & $363.2 \pm 82.1$ & $-0.3 \pm 1.4$ \\
\hline
\end{tabular}

$2.46 \mu \mathrm{g} \mathrm{N}-\mathrm{NH}_{3} \mathrm{~h}^{-1} \mathrm{~g}^{-1}$ respectively). The lowest values corresponded to the control and 12 days starvation groups $\left(2.45 \pm 0.51\right.$ and $3.38 \pm 0.78 \mu \mathrm{g} \mathrm{N}^{-N_{3}} \mathrm{~h}^{-1} \mathrm{~g}^{-1}$ respectively) (ANOVA, $P<0.05$ ) (Fig. 2).
The O:N atomic ratio was significantly lower in the organisms starved for 3 and 6 days $(4.30 \pm 1.05$ and $2.21 \pm 0.86$ respectively). At 9 and 12 days treatments the values (7.26 \pm 3.00 and $8.44 \pm 1.19$ respectively) were similar to the control group (9.58 \pm 2.39 ) (ANOVA, $P<0.05$ ) (Fig. 3).

\section{Biochemical composition of hepatopancreas}

Along starving periods, there were no significant differences in the relative biochemical composition (mean values: water $73.92 \pm 4.94 \%$, organic matter $23.58 \pm 4.84 \%$ and ash $2.50 \pm 0.62 \%$ ). The lipid content (in \%) did not show significant differences among treatments either, but the highest value and deviation was detected in 3 days starvation treatment $(6.40 \pm 2.76 \%)$ and the lowest value at 9 days starving condition $(2.89 \pm 0.86 \%)$. Protein content (in \%) was significantly different among treatments being high at 6 and 9 days starvation treatments $(9.87 \pm 0.33 \%$ and $9.15 \pm 0.40 \%$ respectively). Considering the net amount of lipid in the hepatopancreas, there was no significant differences among treatments, but at 3 days of

Table 2

Hepatosomatic index (HI\%) and relative biochemical composition of the hepatopancreas of Lithodes santolla after each starving period. All values are in average \pm standard deviation

Índice hepatosomático (HI\%) y composición bioquímica proximal del hepatopancreas de Lithodes santolla posterior a cada período de ayuno

\begin{tabular}{|c|c|c|c|c|c|c|}
\hline $\begin{array}{l}\text { Starvation } \\
\text { days }\end{array}$ & HI (\%) & Water (\%) & Organic (\%) & Ash (\%) & $\begin{array}{l}\text { Lipid (\%) } \\
\text { Net lipid } \\
\text { (mg) }\end{array}$ & $\begin{array}{l}\text { Protein }(\%) \\
\text { Net protein }(\mathrm{mg})\end{array}$ \\
\hline 0 (control) & $4.41 \pm 0.22^{a b}$ & $76.30 \pm 0.73$ & $21.24 \pm 0.80$ & $2.46 \pm 0.11$ & $\begin{array}{l}3.03 \pm 0.60 \\
(362.63)\end{array}$ & $\begin{array}{l}7.33 \pm 0.48^{a b} \\
(866.07)\end{array}$ \\
\hline 3 & $5.51 \pm 2.63^{\mathrm{ab}}$ & $71.35 \pm 7.37$ & $26.47 \pm 7.75$ & $2.18 \pm 0.34$ & $\begin{array}{l}6.40 \pm 2.76 \\
(1567.45)\end{array}$ & $\begin{array}{l}8.58 \pm 0.57^{b c} \\
(1459.42)\end{array}$ \\
\hline 6 & $4.39 \pm 1.03^{\mathrm{ab}}$ & $74.80 \pm 4.49$ & $22.61 \pm 4.78$ & $2.59 \pm 0.31$ & $\begin{array}{l}4.40 \pm 1.17 \\
(411.36)\end{array}$ & $\begin{array}{l}9.87 \pm 0.33^{c} \\
(897.39)\end{array}$ \\
\hline 9 & $5.14 \pm 0.15^{\mathrm{a}}$ & $71.88 \pm 6.37$ & $25.24 \pm 5.08$ & $2.88 \pm 1.32$ & $\begin{array}{l}2.89 \pm 0.86 \\
(319.47)\end{array}$ & $\begin{array}{l}9.15 \pm 0.40^{c} \\
(835.74)\end{array}$ \\
\hline 12 & $3.04 \pm 0.24^{b}$ & $75.25 \pm 3.66$ & $22.32 \pm 3.68$ & $2.40 \pm 0.20$ & $\begin{array}{l}4.43 \pm 1.21 \\
(426.89)\end{array}$ & $\begin{array}{l}6.89 \pm 0.29^{a} \\
(687.82)\end{array}$ \\
\hline
\end{tabular}

Values in the same column sharing different letter indicate significant differences $(P<0.05)$ between starving periods. Values are expressed as percentage of mass of the total wet mass of the hepatopancreas. Values in parentheses indicate the average of total hepatopancreatic content in $\mathrm{mg}$.

Los valores en una misma columna con diferente letra indican diferencias significativas $(P<0.05)$ entre los períodos de ayuno. Los valores se expresan como porcentaje de masa del total de peso fresco del hepatopancreas. Valores en paréntesis indican el promedio del contenido total en hepatopáncreas en mg. 


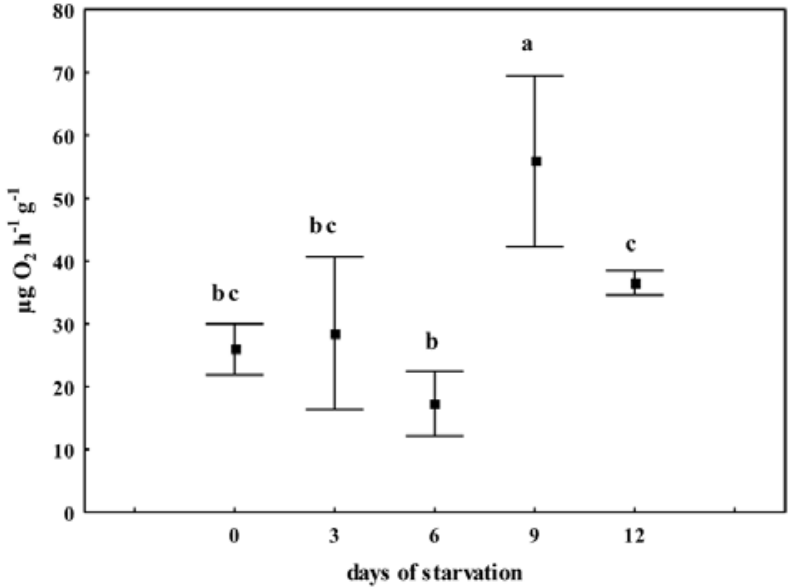

Figure 1

Routine oxygen consumption of Lithodes santolla after each starvation period. Dark points indicate averages and vertical lines indicate standard deviations. Different letters denote significant differences among treatments $(P<0.05)$

Consumo de oxígeno de Lithodes santolla a diferentes períodos de ayuno. Puntos negros indican el promedio y las líneas verticales indican las desviaciones estándares.

Letras diferentes indican diferencias significativas entre los tratamientos $(P<0.05)$

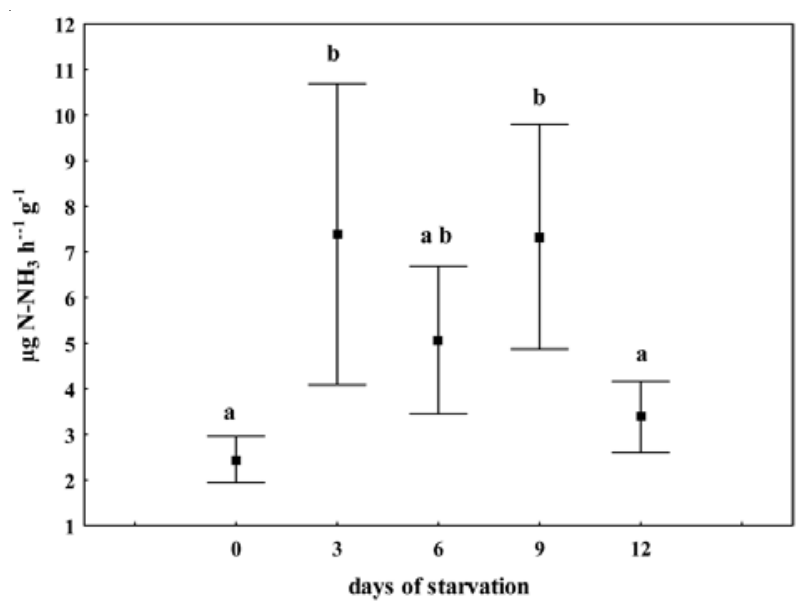

Figure 2

Routine nitrogen excretion of $L$. santolla after each starving period. Dark points indicate averages and vertical lines indicate standard deviations. Different letters denote significant differences among treatments $(P<0.05)$

Excreción nitrogenada de $L$. santolla a diferentes períodos de ayuno. Puntos negros indican el promedio y las líneas verticales indican las desviaciones estándares. Letras diferentes indican diferencias significativas entre los tratamientos $(P<0.05)$

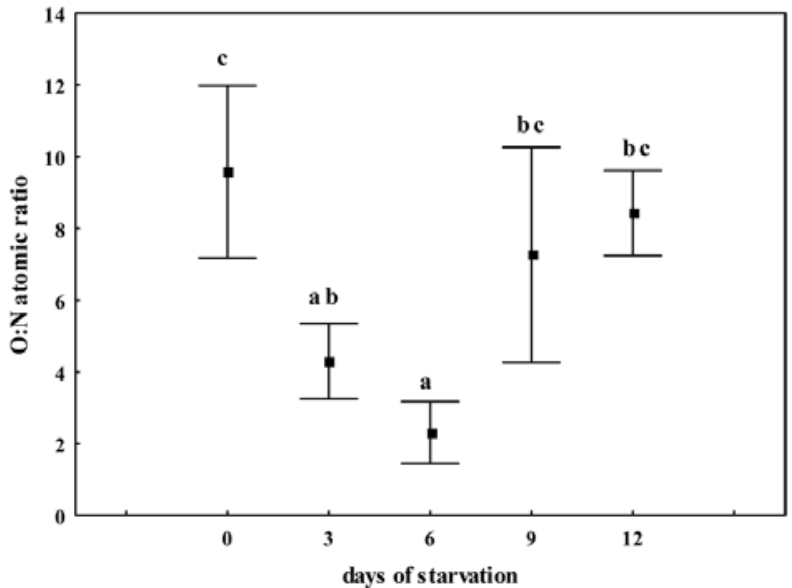

Figure 3

O:N atomic ratio of $L$. santolla after each starving period. Dark points indicate averages and vertical lines indicate standard deviations. Different letters denote significant differences among treatments $(P<0.05)$

Relación atómica O:N de L santolla a diferentes períodos de ayuno. Puntos negros indican el promedio y las líneas verticales indican las desviaciones estándares. Letras diferentes indican diferencias significativas entre los tratamientos $(P<0.05)$

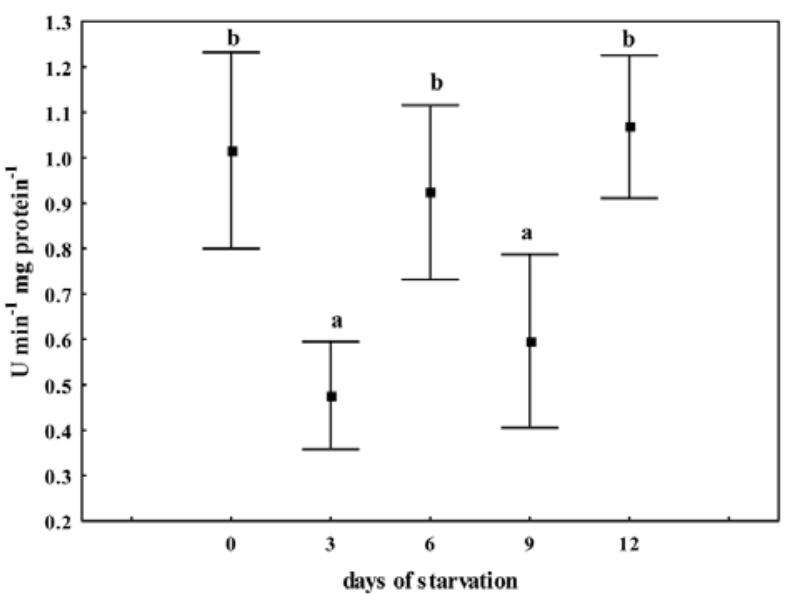

Figure 4

Trypsin activity of $L$. santolla after each starving period. Dark points indicate averages and vertical lines indicate standard deviations. Different letters denote significant differences among treatments $(P<\mathbf{0 . 0 5})$

Actividad enzimática de tripsina de $L$. santolla a diferentes períodos de ayuno. Puntos negros indican el promedio y las líneas verticales indican las desviaciones estándares. Letras diferentes indican diferencias significativas entre los tratamientos $(P<0.05)$ 
starvation the average lipid content was the highest (mean value $1567.45 \mathrm{mg}$ ). Respect to protein content the same tendency was observed at 3 days of starved conditions (mean value $1459.42 \mathrm{mg}$ ) and at 12 days treatment a significant decrease was registered (mean value 687.82 mg) (ANOVA, $P<0.05$ ) (Table 2).

\section{Trypsin activity}

The activity of trypsin was lower at 3 and 9 days starving periods $\left(0.48 \pm 0.12\right.$ and $0.60 \pm 0.19 \mathrm{U} \mathrm{min}^{-1} \mathrm{mg} \mathrm{protein}^{-1}$ respectively) (Fig. 4). The other treatments did not show significant differences with the control group (mean value $1.00 \pm 0.19 \mathrm{U} \mathrm{min}^{-1} \mathrm{mg}$ protein $^{-1}$ ) (ANOVA, $P<0.05$ ).

\section{Discussion}

Due to the spatial and temporal food patchiness in the environment, nutritional deprivation is a natural part of the life cycle of many aquatic organisms (Mehner \& Wieser 1994). The $100 \%$ survival of $L$. santolla in the present study showed the capacity of tolerance to starving conditions for 12 days in coincidence with what has been observed by Comoglio et al. $(2004,2005)$ for Litopenaeus vannamei and Paralomis granulosa respectively, exposed to starvation for similar periods.

The energy metabolism of crustaceans is characterized by high intra- and inter-specific variability, which makes it difficult to determine a standard metabolic profile (Oliveira et al. 2003). Most species reduce their metabolic rate and deplete protein, glycogen and lipid reserves during nutritional stress (Vinagre \& Da Silva 1992, Oliveira et al. 2004, Comoglio et al. 2005). The relative importance of these reserves and their order of utilization vary according to the species, recent feeding history, diet composition and length of fast (Clifford \& Brick 1983, Vinagre \& Da Silva 2002, Vinagre et al. 2007). Some authors have mentioned that the metabolism in crustaceans is primarily based in glycogen and fatty acids (Welsh 1975, Wen et al. 2006), but in contrast decreased levels of protein have been noted during fasting in other marine decapods (Barclay et al. 1983, Dall \& Smith 1986).

Starvation affects metabolic activities and during this period essential processes are maintained at the expense of accumulated endogenous energy reserves, which sometimes results in a loss of weight (Steffens 1989). However, some authors have detected that some crustaceans such as shrimps and lobsters compensate the weight of organic matter that they use in starving conditions with water uptake so that no loss of weight is detected (Dall 1974, Wilcox \& Jeffries 1976). In the present study no changes in wet weight were registered, but we can not confirm that this corresponds to water incorporation; further research is needed to enlighten this effect.

On the other hand, lipids play an important role during the development of decapod crustaceans, not only as energy sources, but also as essential nutrients (Kanazawa et al. 1985). In the present study the decrease in hepatosomatic index observed in crabs starved for 12 days showed to be associated with the protein content, which was lower for this period, and not with the lipid content that remained constant along starving periods.

Between the 3 and 9 days of fasting period the increment in protein content of hepatopancreas, the increase of ammonia excretion and the low values of $\mathrm{O}: \mathrm{N}$ could indicate, as mentioned by Mayzaud \& Conover (1988), that the catabolism of protein was predominant. These authors have established that values between 3 and 16 would be possible for protein-dominated catabolism; this theoretical minimum was calculated for zooplankton species so that some variations could appear depending on the species considered.

In general terms, digestive enzymes follow the presence or absence of food. Samain et al. (1983) and Cuzon et al. (1980) have found that digestive enzymes increase in case of food deprivation with a peak, and then the enzyme production decreases as an adaptation to low nutrition status and to save energy. So these lower values (at 3 and 9 days of starving conditions) could be related to the mobilization of their own reserves, corresponding with the highest excretion of ammonia and higher values in hepatopancreas that indicated a dominating protein metabolism.

Taking into account that $1 \mathrm{~g}$ of protein requires $0.94 \mathrm{~L}$ of oxygen in oxidative metabolism and that $1 \mathrm{~g}$ of lipid requires 2.04 L (Mayzaud \& Conover 1988), the increase in oxygen consumption detected at 9 days of the experiment accompanied with high value of ammonia excretion may be indicating an extra energy demand was produced by the starving and not by the use of lipids. Comparing the present results with the ones obtained previously for P. granulosa (Comoglio et al. 2005), we could conclude that both species, that co-inhabit the Beagle Channel, have different patterns of response to starvation, denoting in $L$. santolla the priority use of proteins in contrast with the use of lipids for $P$. granulosa for the same experimental time-range study.

The ability to withstand and recover from periods of nutritional stress is an important adaptation for survival of any organism that must sporadically endure periods of limited food supply (Stuck et al. 1996). For L. santolla although there were no significant differences detected 
in the relative quantity of food consumed between seasons among mature crabs, during spring months the percentage of empty stomachs was higher and differences in the occurrence of different types of food was detected (Comoglio \& Amin 1996). In general terms, for crab species feeding takes place throughout the year, except during a few weeks of the molting-mating period, when feeding ceases or is at a minimum (Jewett \& Feder 1982). In this sense, the results of the present study give new and relevant biological information about the physiological and biochemical responses during starving condition about an important commercial species that inhabits the Beagle Channel.

\section{Acknowledgments}

This study was supported by National Research Council (CONICET) and PICTR 090-2002 ANPCyT. Special thanks to Pesquera del Beagle S.A. for providing the animals. We are grateful to Ricardo Saenz-Samaniego, Gladys Esperanza and Andres Vallejos for technical assistance and to Lic María Laura Borla for the final English revision. Thanks also to the anonymous reviewers for their valuable considerations.

\section{Literature cited}

Barclay MC, W Dall \& DM Smith. 1983. Changes in lipid and protein during starvation and the moulting cycle in the tiger prawn, Penaeus esculentus (Haswell). Journal of Experimental Marine Biology and Ecology 68: 229-244.

Bligh EG \& WJ Dyer. 1959. A rapid method of total lipid extraction and purification. Canadian Journal of Biochemistry 37: 911-917.

Clifford HC \& RW Brick. 1983. Nutritional physiology of the freshwater shrimp Macrobrachium rosenbergii (De Man): I. Substrate metabolism in fasting juvenile shrimp. Comparative Biochemistry and Physiology A 74(3): 561568 .

Comoglio LI \& OAAmin. 1996. Natural diet of the Southern King Crab Lithodes santolla (Lithodidae) in the Beagle Channel, Tierra del Fuego, Argentina. Biología Pesquera 25: 51-57.

Comoglio LI, G Gaxiola, A Roque, G Cuzon \& O Amin. 2004. The effect of starvation on refeeding, digestive enzyme activity, oxygen consumption and ammonia excretion in juvenile white shrimp Litopenaeus vannamei. Journal of Shellfish Research 23(1): 243-249.

Comoglio L, L Smolko \& O Amin. 2005. Effects of starvation on oxygen consumption, ammonia excretion and biochemical composition of the hepatopancreas on adult males of the False Southern King Crab Paralomis granulosa (Crustacea, Decapoda). Comparative Biochemistry and Physiology B 140: 411-416.
Chu K \& NN Ovsianico-Koulikowsky. 1994. Ontogenetic changes in metabolic activity and biochemical composition in the shrimp, Metapenaeus ensis. Journal of Experimental Marine Biology and Ecology 183:11-26.

Cuzon G, C Cahu, JF Aldrin, JL Messager, G Stephan \& M Mevel. 1980. Starvation effect of metabolism of Penaeus japonicus. Proceedings of World Mariculture Society 11:410-430.

Dall W. 1974. Indices of nutritional state in the western rock lobster Panulirus longipes (Milne-Edwards): I. Blood and tissue constituents and water content. Journal of Experimental Marine Biology and Ecology 16: 176-180.

Dall W \& DM Smith. 1986. Oxygen consumption and ammonia excretion in fed and starved tiger prawns, Penaeus esculentus Haswell. Aquaculture 55: 23-33.

Daniel WW. 1978. Applied Nonparametric Statistics, 503 pp. Houghton Mifflin Company, Boston.

Erlanger BF, N Kokowsky \& W Cohen. 1961. The preparation and properties of two chromogenic substrates of trypsin. Archives of Biochemistry and Biophysics 95: 271-278.

Fernandez I, M Oliva, O Carrillo \& A van Wormhoudt. 1997. Digestive enzyme activities of Penaeus notialis during reproduction and moult cycle. Comparative Biochemistry and Physiology 118: 1267-1271.

Guderley H, D Lapointe, M Bedard \& JD Dutil. 2003. Metabolic priorities during starvation: enzyme sparing in liver and white muscle of Atlantic cod, Gadus morhua L. Comparative Biochemistry and Physiology A 135: 347-356.

Hasek BE \& DL Felder. 2005. Biochemical composition of ovary, embryo, and hepatopancreas in the grapsoid crabs Armases cinereum and Sesarma nr. reticulatum (Crustacea, Decapoda). Comparative Biochemistry and Physiology B 140: 455-463.

Jewett SC \& HM Feder. 1982. Food and feeding habits of the king crab Paralithodes camtschatica near Kodiak Island, Alaska. Marine Biology 66: 243-250.

Kanazawa A, S Teshima \& M Sakamoto. 1985. Effects of dietary lipids, fatty acids, and phospholipids on growth and survival of prawn (Penaeus japonicus) larvae. Aquaculture 50: 39-49.

Leung KM, HL Chen \& KH Chu. 1990. Effects of starvation on biochemical composition and digestive enzyme activities in the hepatopancreas of the shrimp Metapenaeus ensis. Proceedings of the Second Asian Fisheries Forum, Tokyo, Japan, pp. 445-448.

Mayzaud P. 1976. Respiration and nitrogen excretion of zooplankton: IV. The influence of starvation on the metabolism and the biochemical composition of some species. Marine Biology 37: 47-58.

Mayzaud P \& RJ Conover. 1988. O:N atomic ratio as a tool to describe zooplankton metabolism. Marine Ecology Progress Series 45: 289-302. 
Markwell MA, SM Haas, LL Bieber \& NE Tolbert. 1978. A modification of the Lowry procedure to simplify protein determination in membrane and lipoprotein samples. Analytical Biochemistry 87: 206-210.

Mehner T \& W Wieser. 1994. Energetics and metabolic correlates of starvation in juvenile perch (Perca fluviatilis). Journal of Fish Biology 45: 325-333.

Oliveira GT, FA Fernandes, G Bond-Buckup, AA Bueno \& RSM Da Silva. 2003. Circadian and seasonal variations in the metabolism of carbohydrates in Aegla ligulata (Crustacea: Anomura: Aeglidae). Memoirs of Museum Victoria 60: 59-62.

Oliveira GT, IC Rossi, LCR Kucharski \& RSM Da Silva. 2004. Hepatopancreas gluconeogenesis and glycogen content during fasting in crabs previously maintained on a high-protein or carbohydrate-rich diet. Comparative Biochemistry and Physiology A 137: 383-390.

Regnault M. 1981. Respiration and ammonia excretion of the shrimp Crangon crangon (L.). Metabolic responses to prolonged starvation. Journal of Comparative Physiology 141: 549-555.

Rodriguez A, L Le Vay, G Mourente \& DA Jones. 1994. Biochemical composition and digestive enzyme activity in larvae and postlarvae of Penaeus japonicus during herbivorous and carnivorous feeding. Marine Biology 118: 45-51.

Rosas CS, A Sánchez, E Diaz, LA Soto, G Gaxiola, R Brito, M Baes \& R Pedroza. 1995. Oxygen consumption and ammonia excretion of Penaeus setiferus, $P$. schmitti, $P$. duorarum and $P$. notialis postlarvae fed purified test diets: effect of protein levels on substrate metabolism. Aquatic Living Resources 8: 161-169.

Rosas C, G Cuzon, G Gaxiola, C Pascual, R Brito, ME Chimal \& A van Wormhoudt. 2000. El metabolismo de los carbohidratos de Litopenaeus setiferus, L. vannamei, y L. stylirostris. In: Cruz-Suarez, LE, D Ricque-Marie, MA Tapia-Salazar \& R Civera-Cerecedo (eds), Avances en Nutrición Acuícola V. Memorias del Quinto Simposium Internacional de Nutrición Acuícola. 19-22 Noviembre, 2000. Mérida, Yucatán, pp. 340-359.

Samain JF, J Moal, JR Le Coz \& JY Daniel. 1983. Amylase et trypsine du zooplancton et surveillance du milieu pélagique. In: Bretagne Cabioch L, M Glemarec \& JF Samain (eds). 17th European Symposium on Marine Biology, Brest, France: Oceanologica Acta, pp. 177-182.

Sánchez-Paz A, F García-Carreño, A Muhlia-Almazan, AB Peregrino-Uriarte, J Hernández-López \& G YepizPlascencia. 2006. Usage of energy reserves in crustaceans during starvation: Status and future directions. Insect Biochemistry and Molecular Biology 36: 241-249.

Sánchez-Paz A, F García-Carreño, J Hernández-López, A Muhlia-Almazan \& G Yepiz-Plascencia. 2007. Effect of short-term starvation on hepatopancreas and plasma energy reserves of the Pacific white shrimp (Litopenaeus vannamei). Journal of Experimental Marine Biology and Ecology 340: 184-193.

Sang HM \& R Fotedar. 2004. Growth, survival, haemolymph osmolality and organosomatic indices of the western king prawn (Penaeus latisulcatus Kishinouye, 1896) reared at different salinities. Aquaculture 234: 601-614.

Sokal RR \& F J Rohlf. 1981. Biometría. Principios y métodos estadísticos en la investigación biológica. 832 pp. Editorial Blume, Madrid.

Steffens W. 1989. Principles of Fish Nutrition, 384 pp. Ellis Horwood, Chichester.

Stuck KC, SA Watts \& SY Wang. 1996. Biochemical responses during starvation and subsequent recovery in postlarval Pacific white shrimp, Penaeus vannamei. Marine Biology 125: 33-45.

Strickland JDH \& TR Parsons. 1972. A practical handbook of seawater analysis. Fisheries Research Board of Canada, Bulletin 167: 1-311.

Sureshkumar S \& B Kurup. 1999. Variations in hepatosomatic index and biochemical profiles among the male morphotypes of Macrobrachium rosenbergii. Aquaculture 176: 285-293.

Taboada G, G Gaxiola, T García, R Pedroza, A Sánchez, LA Soto \& C Rosas. 1998. Oxygen consumption and ammonia$\mathrm{N}$ excretion related to protein requirements for growth of white shrimp, Penaeus setiferus (L), juveniles. Aquaculture Research 29: 822-833.

van Wormhoudt A. 1974. Variations of the level of the digestive enzymes during the intermolt cycle of Palaemon serratus: influence of the season and effect of the eyestalk ablation. Comparative Biochemistry and Physiology 49: 707-715.

Vazquez Boucard CG, J Patrois \& HJ Ceccaldi. 2004. Exhaustion of lipid reserves in the hepatopancreas of Fenneropenaeus indicus broodstock in relation to successive spawnings. Aquaculture 236: 523-537.

Vinagre AS \& RSM Da Silva. 1992. Effects of starvation on the carbohydrate and lipid metabolism in crabs previously maintained on a high-protein or carbohydrate-rich diet. Comparative Biochemistry and Physiology A 102: 579-583.

Vinagre AS \& RSM Da Silva. 2002. Effects of fasting and refeeding on metabolic processes in the crab Chasmagnathus granulatus (Dana, 1851). Canadian Journal of Zoology 80: 1413-1421.

Vinagre AS, AP Nunes do Amaral, FP Ribarcki, E Fraga da Silveira \& E Périco. 2007. Seasonal variation of energy metabolism in ghost crab Ocypode quadrata at Siriu Beach (Brazil). Comparative Biochemistry and Physiology A 146: 514-519.

Vinuesa JH. 1984. Sistema reproductor, ciclo y madurez gonadal de la centolla (Lithodes antarcticus) del Canal Beagle. In: Estudio biológico-pesquero de la centolla ( $L$. 
antarcticus) del Canal Beagle, Tierra del Fuego. Contribución INIDEP 441: 75-95.

Welsh BL. 1975. The role of grass shrimp Palaemonetes pugio in a tidal marsh ecosystem. Ecology 56: 513-530.

Wen X, L Chen, Y Ku \& K Zhou. 2006. Effect of feeding and lack of food on the growth, gross biochemical and fatty acid composition of juvenile crab, Eriocheir sinensis. Aquaculture 252: 598-607.
Wilcox JR \& HP Jeffries. 1976. Hydration in the sand shrimp Crangon septemspinosa: relation to diet. The Biological Bulletin 150: 522-530.

Ying XP, WX Yang \& YP Zhang. 2006. Comparative studies on fatty acid composition of the ovaries and hepatopancreas at different physiological stages of the Chinese mitten crab. Aquaculture 256: 617-623.

Recibido el 28 de agosto de 2007 y aceptado el 28 de mayo de 2008 